\title{
Evaluation of Phyto-ashes for Agri-environmental Goals - A Novel Approach
}

\author{
Jean Diatta* \\ Department of Agricultural Chemistry and Environmental Biogeochemistry, University of Life Sciences, Poland
}

Submission: November 25, 2019; Published: December 02, 2019

*Corresponding author: Jean Diatta, Department of Agricultural Chemistry and Environmental Biogeochemistry, University of Life Sciences, Poznan, Poland

\section{Summary}

The concept of the current research was based on the readaptation of the acid neutralising capacity (ANC) for agri-environmental use of phyto-ashes. For this purpose, 9 phyto-ashes from birch (Betula), oak (Quercus), red oak (Quercus rubra), hornbeam (Carpinus), pine (Pinus sylvestris), poplar (Populus), maple (Acer), wheat straw (Triticum aestivum) and oilseed rape straw (Brassica napus) have been tested for their $\mathrm{pH}$ as well as $\mathrm{Ca}, \mathrm{Mg}, \mathrm{K}, \mathrm{Na}$ and $\mathrm{SiO}_{2}$. A novel approach was suggested for using the $\mathrm{CaO} / \mathrm{SiO}_{2}$ ratio in the evaluation of the geo-structural potential (flocculation effect) of phyto-ashes to soil medium.

Keywords: Phyto-ash; Acid neutralising capacity (ANC); Geochemistry, $\mathrm{CaO} / \mathrm{SiO}_{2}$ ratio

\section{Information}

Burning plant biomass is a process accompanying human kind since the early beginning. The residues, i.e., phyto-ashes have been used as potash component or soil improvers, hence they are probably the earliest ever known mineral fertilizers in the human history. The industrial recovery of energy (bioenergy or green energies) by incinerating plant biomass generates huge amounts of phyto-ashes which are recycled for various purposes [1]. Their application as liming materials as well as fertilizers was desisted at the eve of the $20^{\text {th }}$ century, due to the emergence of alternative products like lime and muriate of potash, [2]. With the progressive exhaustion of phosphate and potassium reserves phyto-ashes should be a valuable renewable resource agrienvironmental goals $[3,4]$ including, silviculture too. Degraded soils are particularly concerned.

One of the key parameters taking into consideration when applying phyto-ashes for agri-environmental goals is the reactivity expressed both by high alkalinity (reactivity) and the concentrations of basic metals ( $\mathrm{Ca}, \mathrm{Mg}, \mathrm{K}$ and $\mathrm{Na}$ ). This parameter (acid neutralizing capacity-ANC) may be determined by laboratory titration, but also evaluated empirically by the relationship outlined by MDDEP [5]: ANC (\%) = (\%Ca.2.5) + $\left(\% \mathrm{~K}^{\cdot 1.2}\right)+(\% \mathrm{Mg} \cdot 4.2)$. The lack of sodium (Na) implies that the relationship is applicable for much more homogenic plant biomass, like wood. Other phyto-ashes with appreciable levels of Na, may exhibit distinct ANC.

The concept of the current research was based on the readaptation of the empirical ANC [5]. For this purpose, nine phyto-ashes from birch (Betula), oak (Quercus), red oak (Quercus rubra), hornbeam (Carpinus), pine (Pinus sylvestris), poplar (Populus), maple (Acer), wheat straw (Triticum aestivum) and oilseed rape straw (Brassica napus) have been tested for their $\mathrm{pH}$ and chemical composition ( $\mathrm{Ca}, \mathrm{Mg}, \mathrm{K}, \mathrm{Na}$ and $\mathrm{SiO}_{2}$ ). A novel approach has been elaborated for evaluating the geo-structural potential of phyto-ashes to soil medium.

\section{Materials and Methods}

Phyto-ash samples originated from the incineration at $600^{\circ} \mathrm{C}$ for 4 hours in a muffle furnace [6] of 7 wood parts with barks and 2 straws of crop plants. The recovered ashes are listed as below:

a) 7 wood ashes from birch (Betula), oak (Quercus), red oak (Quercus rubra), horbeam (Carpinus), pine (Pinus sylvestris), poplar (Populus), maple (Acer).

b) 2 crop plant ashes: wheat (Triticum aestivum), oilseed rape (Brassica napus).

The chemical composition, i.e. the content of $\mathrm{Ca}, \mathrm{Mg}$, $\mathrm{K}, \mathrm{Na}$ and $\mathrm{SiO} 2$ was determined by the XRD spectrometry fluorescence method additionally with the minerology by using the diffractometer D8 Discover (Bruker), with the ray $\mathrm{CuK} \alpha, \mathrm{Ni}$ filter and Lynxeye detector. Next phyto-ashes were analysed for $\mathrm{pH}$ in aqueous (double distilled water) suspension at the ratio as 1 to $2.5\left(10 \mathrm{~g} / 25 \mathrm{ml} \mathrm{H}_{2} \mathrm{O}\right)$. The slurries were shaken for $1 \mathrm{~h}$ on a rotatory shaker, after they were left to equilibrate for 1 hour 
before $\mathrm{pH}$ measurements by using a pH-meter (Elmetron $\mathrm{CX}$ 701).

\section{Data and Comments}

The chemical composition of phyto-ashes (Table 1) revealed, that $\mathrm{pH}$ is highly alkaline $\left(\mathrm{pH}_{\mathrm{H} 20}: 11.5\right.$ - 13.6), but slightly less for phyto-ashes obtained from crop plants. One of the parameter which deserves attention is the content of $\mathrm{SiO}_{2}$. The relationship of $\mathrm{CaO}$ to this compound generated the following equation: $\% \mathrm{SiO}_{2}=470.4 \cdot(\% \mathrm{CaO})^{-1.15} \mathrm{R}^{2}=0.809 ; \mathrm{n}=9$. Such relationship assumes, that $\mathrm{SiO}_{2}$ may be a key factor, significantly regulating the chemical behavior of $\mathrm{CaO}$, expressed among others by the acid neutralizing capacity (ANC) parameter [5].

Table 1: Reaction, content of alkaline elements and silicon oxide of chalk lime and investigated phytoashes.

\begin{tabular}{|c|c|c|c|c|c|c|}
\hline \multirow{2}{*}{ Material / Phytoash } & \multirow{2}{*}{$\mathrm{pH}_{\mathrm{H20}}$} & $\mathrm{CaO}$ & MgO & $\mathrm{K}_{2} \mathrm{O}$ & $\mathrm{Na}_{2} \mathrm{O}$ & $\mathrm{SiO}_{2}$ \\
\hline & & \multicolumn{5}{|c|}{$\%$} \\
\hline Chalk lime $\left(\mathrm{CaCO}_{3}\right)$ & 8.2 & 43.4 & 5.81 & 0.04 & 0 & \\
\hline Birch (Betula) & 13.2 & 35 & 4.35 & 7.36 & 0.87 & 7.81 \\
\hline Oak (Quercus) & 12.9 & 36.4 & 1.4 & 8.07 & 0.87 & 7.13 \\
\hline Red Oak (Quercus rubra) & 13.4 & 32.9 & 1.56 & 9.13 & 1.05 & 13.36 \\
\hline Horbeam (Carpinus) & 13.6 & 39.5 & 4.72 & 8.36 & 0.81 & 6.74 \\
\hline Pine (Pinus sylvestris) & 13.4 & 38.4 & 3.28 & 5.49 & 1.02 & 8.46 \\
\hline Poplar (Populus) & 13.6 & 26.5 & 4.55 & 30.7 & 0.69 & 4.57 \\
\hline Maple (Acer) & 13.2 & 45.1 & 2.36 & 5.93 & 0.67 & 5.96 \\
\hline Wheat straw (Triticum aestivum) & 11.5 & 7.45 & 2.48 & 9.4 & 0.91 & 58.3 \\
\hline Oilseed rape straw (Brassica napus) & 12.6 & 10 & 2.4 & 21.7 & 0.52 & 29.3 \\
\hline
\end{tabular}

According to Hébert et Breton [3], divalent alkaline elements ( $\mathrm{Ca}, \mathrm{Mg}$ ) exhibit a flocculating potential once in the soil medium, whereas monovalent elements ( $\mathrm{K}$ and $\mathrm{Na}$ ), the dispersing effect. Therefore, their ratio should be indicative of any soil structure forming or not. On this basis, a concept was developed, where phyto-ash $\mathrm{SiO}_{2}$, also as a prevailing soil constituent has been considered, resulting in $\mathrm{CaO} / \mathrm{SiO}_{2}$ ratio (Table 2).

Table 2: Reaction, content of alkaline elements and silicon oxide of chalk lime and investigated phytoashes.

\begin{tabular}{|c|c|c|c|}
\hline \multirow{2}{*}{ Material/Phytoash } & $\mathrm{ANC}^{\mathrm{a}}$ & Geo-Struct ${ }^{b}$ & Ratio $^{d}$ \\
\hline & $\%$ & $\%(\mathrm{Ca}+\mathrm{Mg}) / \%(\mathrm{~K}+\mathrm{Na})$ & $\mathrm{CaO} / \mathrm{SiO}_{2}$ \\
\hline Chalk lime $\left(\mathrm{CaCO}_{3}\right)$ & 100 & 1050 & \\
\hline Birch (Betula) & 81 & 4.09 & 4.48 \\
\hline Oak (Quercus) & 103 & 5.06 & 5.1 \\
\hline Red Oak (Quercus rubra) & 78 & 3.22 & 2.46 \\
\hline Horbeam (Carpinus) & 91 & 3.67 & 5.86 \\
\hline Pine (Pinus sylvestris) & 83 & 5.55 & 4.54 \\
\hline Poplar (Populus) & 90 & 0.84 & 5.81 \\
\hline Maple (Acer) & 93 & 6.27 & 7.56 \\
\hline Wheat straw (Triticum aestivum) & 29 & 0.81 & 0.13 \\
\hline $\begin{array}{c}\text { Oilseed rape straw (Brassica } \\
\text { napus) }\end{array}$ & 46 & 0.47 & 0.34 \\
\hline Threshold value & - & $2.5^{\mathrm{c}}$ & $1.0^{\mathrm{e}}$ \\
\hline
\end{tabular}

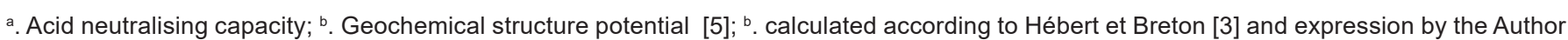
of the current paper; ${ }^{c}$. according to Hébert et Breton [3]; ${ }^{d}$. concept by the Author of the current paper; ${ }^{\mathrm{e}}$. outcome from Figure 1.

A state-of-the-art graphical output (Figure 1) has been obtained for the pairs $\mathrm{CaO} / \mathrm{SiO}_{2}$ ratio versus $\mathrm{CaO}(\%)$ and $\mathrm{SiO}_{2}$ (\%). The intersection of both curves represents the value, i.e., threshold value below, which the geochemical structure potential exerted by a given phyto-ash once incorporated to the soil is weak. In another words, the flocculation process leading to a good soil structure is less efficient. 


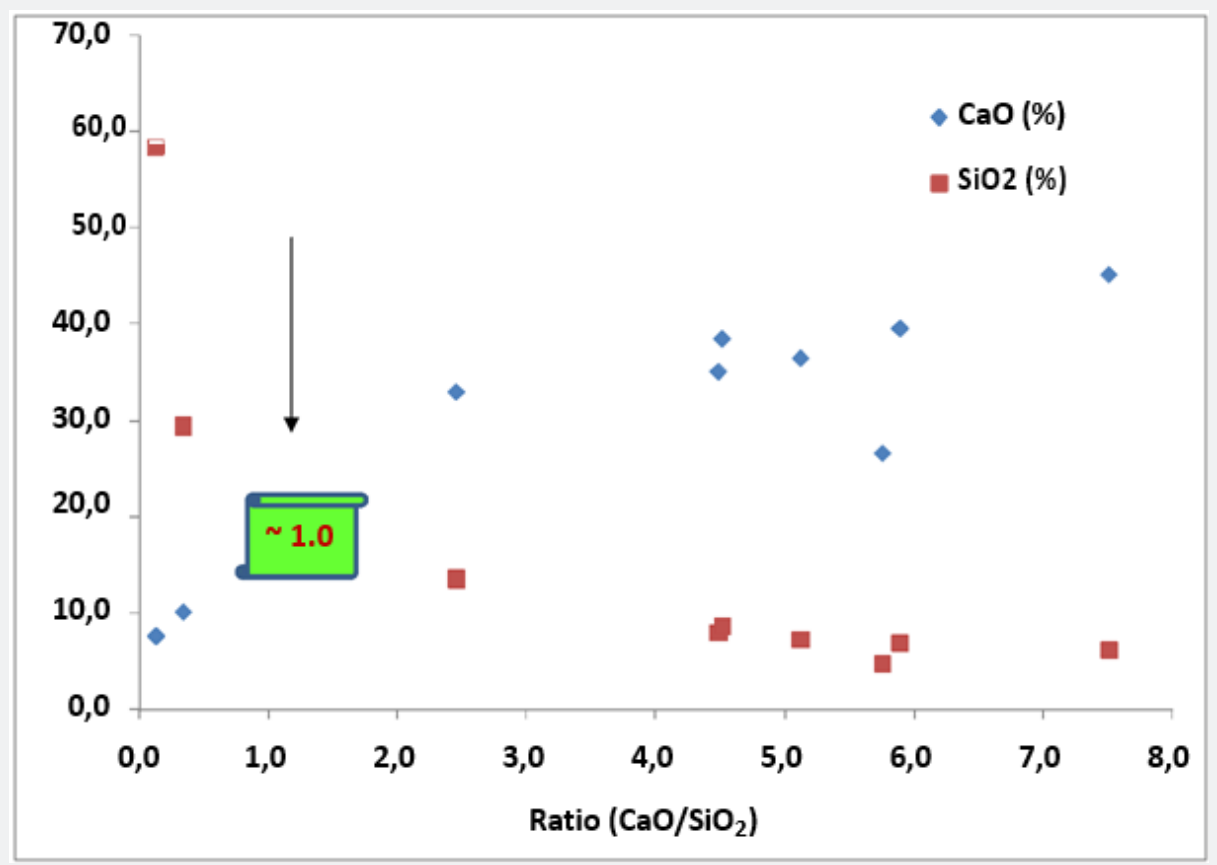

Figure 1: Relationship between $\mathrm{CaO} / \mathrm{SiO}_{2}$ ratio and $\mathrm{CaO}$ content of investigated phytoashes (more details, refer to Table $1 \& 2$ ).

The use of the $\%(\mathrm{Ca}+\mathrm{Mg}) / \%(\mathrm{~K}+\mathrm{Na})$ parameter [5] with the 2.5 as threshold value (Table 2) discriminated 3 phyto-ashes: poplar, wheat and oilseed rape. In the case of the current (i.e. 1.0) value, only the 2 last ones were below this value.
This novel approach implies, that the $\mathrm{CaO} / \mathrm{SiO}_{2}$ ratio is a simple and reliable parameter in evaluating the potential capacity of any phyto-ash for flocculating soil colloids and hence, forming appreciable structure.

\section{Future Research Prospects}

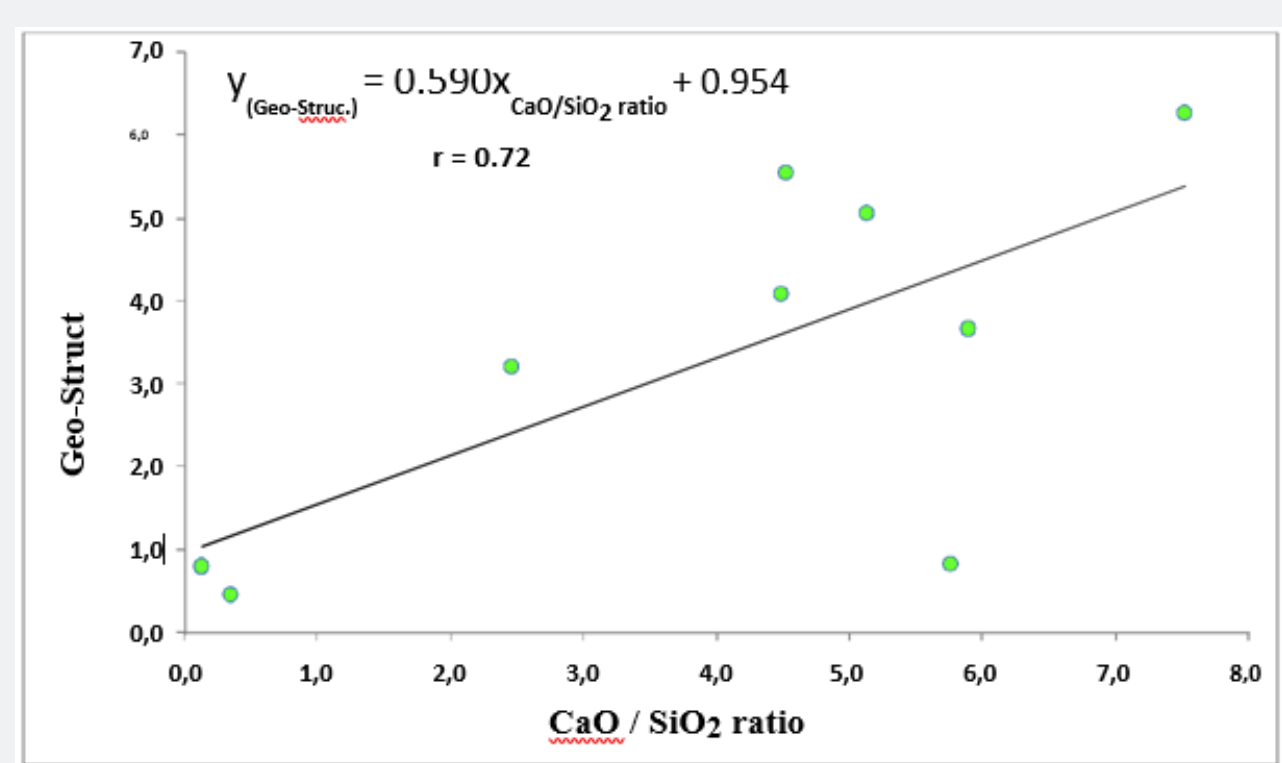

Figure 2: Relationship between $\mathrm{CaO} / \mathrm{SiO}_{2}$ ratio and $\mathrm{CaO}$ content of investigated phytoashes (more details, refer to Table $1 \& 2$ ).

Bioenergy recovering is currently a worldwide broad practice, since performing of renewable environmental resources - plant biomass. Its mineral composition derives from soil reserves, hence the urgent need for incorporating back these elements, in an appropriate way.
Relevant indices like $\mathrm{CaO} / \mathrm{SiO}_{2}$ ratio (Figure 2) are worth implementing broadly. The generated relationship with the coefficient of correlation $(r=0.72)$, supports the concept developed herein. 


\section{References}

1. (2018) Circular Economy Package.

2. Maltas A, Sinaj S (2014) Wood ash: a new fertilizer for Swiss agriculture. Recherche Agronomique Suisse 5(6): 232-239.

3. Hébert M Breton B (2008) Agricultural recycling of wood ash in Quebec - state, impacts and good agro-environmental practices. Agrosolutions 19: 18-33.

4. Vassilev SV, Baxter D, Andersen L, Vassileva C (2013a) An overview of the composition and application of biomass ash. Part 2. Potential utilization, technological and ecological advantages and challenges. Fuel 105: 19-39.

5. MDDEP (2008) Guide sur la valorisation des matières résiduelles fertilisantes. Critères de réferences et normes réglementaires. Environnement Québec, p. 127.

6. Xiao R, Chen X, Wang F, Yu G (2011) The physicochemical properties of different biomass ashes at different ashing temperature. Renewable Energy 36(1): 244-249.

Your next submission with Juniper Publishers will reach you the below assets

- Quality Editorial service

- Swift Peer Review

- Reprints availability

- E-prints Service

- Manuscript Podcast for convenient understanding

- Global attainment for your research

- Manuscript accessibility in different formats ( Pdf, E-pub, Full Text, Audio)

- Unceasing customer service

Track the below URL for one-step submission https://juniperpublishers.com/online-submission.php 